\title{
NEW GENUS AND FIRST RECORD OF HYBOTINAE (DIPTERA: EMPIDOIDEA: HYBOTIDAE) IN MIDDLE MIOCENE DOMINICAN AMBER
}

\section{Nuevo género y primer registro de Hybotinae (Diptera: Empidoidea: Hybotidae) en ámbar dominicano del Mioceno medio}

\begin{abstract}
Mónica M. Solórzano-Kraemer ${ }^{*}$, Xavier Delclòs ${ }^{2}$, Enrique Peñalver ${ }^{3}$, and Bradley J. Sinclair ${ }^{4}$
${ }^{1}$ Senckenberg Research Institute, 60325 Frankfurt am Main, Germany; *Para correspondencia: monica.solorzanokraemer@senckenberg.de; (1) orcid.org/0000-0003-3065-119X. 르. Dinàmica de la Terra i de l'Oceà, Facultat de Ciències de la Terra, and Institut de Recerca de la Biodiversitat (IRBio), Universitat de Barcelona, 08028 Barcelona, Spain; xdelclos@ub.edu; (1) orcid.org/0000-0002-2233-5480. ${ }^{3}$ Instituto Geológico y Minero de España (Museo Geominero), 46004 Valencia, Spain; e.penalver@igme.es; (1) orcid.org/0000-0001-8312-6087. ${ }^{4}$ Canadian National Collection of Insects \& Canadian Food Inspection Agency, OPL-Entomology, K.W. Neatby Bldg., C.E.F., 960 Carling Ave., Ottawa, ON, K1A 0C6, Canada; bradley.sinclair@canada.ca.
\end{abstract}

\section{ABSTRACT}

A new fossil genus of the family Hybotidae is described, based on male and female specimens. The new genus is monotypic: Syneproctus caridadi gen. et sp. nov. It belongs to the subfamily Hybotinae and shares some characters with the extant genera Syneches Walker, 1852, Stenoproctus Loew, 1858 and Chillcottomyia Saigusa, 1986; however, the differences, principally in the wing venation (shortened cua cell, horizontal m-cu crossvein) and sclerotized mouthparts, support the description of a new genus. This is the first description of a new taxon of the subfamily Hybotinae from specimens preserved in Dominican amber.

Keywords: Dominican amber, new genus and species, Syneches, Stenoproctus, Chillcottomyia.

\section{RESUMEN}

Se describe un nuevo género de la familia Hybotidae, basado en especímenes de ambos sexos. El nuevo género comprende una única especie: Syneproctus caridadi gen. et sp. nov. Pertenece a la subfamilia Hybotinae y comparte algunos caracteres con los géneros actuales Syneches Walker, 1852, Chillcottomyia Saigusa, 1986 y Stenoproctus Loew, 1858; sin embargo, las diferencias, principalmente en la venación alar (celda cua corta, vena transversa m-cu horizontal), y aparato bucal esclerotizado respaldan la descripción de un nuevo género. Esta es la primera descripción de un nuevo taxon de la subfamilia Hybotinae a partir de especímenes preservados en ámbar dominicano.

Palabras clave: ámbar dominicano, nuevo género y especie, Syneches, Stenoproctus, Chillcottomyia.

\section{INTRODUCTION}

Empidoid flies are abundant in amber, copal, resin and are readily trapped in field actuotaphonomic research using sticky traps (Solórzano-Kraemer et al., 2018). Individuals of the family Hybotidae are relatively common in amber, principally in Cretaceous and Eocene ambers with species described from Spanish, Burmese and Baltic ambers (Penney, 2010). From Miocene amber only the subfamily Tachydromiinae (Diptera, Empidoidea, Hybotidae) has been reported in Mexican and Dominican ambers (Solórzano-Kraemer et al., 2005). 
The new genus is embedded in Dominican amber, which originated from Miocene (20 to 15 my) resin (Iturralde-Vinent \& MacPhee, 1996; Iturralde-Vinent, 2001; Iturralde-Vinent $\&$ MacPhee, 2019). The plant source of the fossil resin is considered to be a representative of the genus Hymenaea Linnaeus, 1753, the fossil species Hymenaea protera Poinar, 1991, which is closely related to extant $H$. verrucosa Gaertner, 1791, from east Africa and Madagascar.

The new genus herein described belongs to the subfamily Hybotinae on the basis of the holoptic female, stout and obliquely projecting proboscis, wing broad with two veins emitted from wing cell $\mathrm{dm}$ and prosternum isolated and separated from the proepisternum (Sinclair \& Cumming, 2006). The subfamily Hybotinae is today known from the Dominican Republic with three genera recorded: Euhybus Coquillett, 1895, Neohybus Ale-Rocha \& Carvallo, 2003 and Syneches Walker, 1852. Neohybus is restricted to Neotropical Americas (Ale-Rocha \& Rafael, 2004), whereas Euhybus has been recorded beyond the New World, but the definition of the genus needs to be re-examined (Sinclair \& Cumming, 2017). Syneches is cosmopolitan in distribution and broadly dispersed with approximately 189 species described (Menezes \& Ale-Rocha, 2016). Most species of Syneches occur in tropical regions. In America, the genus is widespread from southern Canada, to the south of Brazil and the Antilles (Wilder, 1974; Menezes \& Ale-Rocha, 2016). The Hybotinae are predaceous flies living in various forest habitats, with adults capturing prey during flight (Sinclair \& Cumming, 2017).

\section{OBJECTIVE}

- To increase the knowledge of the Caribbean paleoentomofauna based on the study of new and uncommon insect specimens preserved in Miocene Dominican amber, as is the case of the first description herein of a new fossil taxon of the subfamily Hybotinae from this amber.

\section{MATERIALS AND METHODS}

The pieces of amber with the three specimens described herein (Fig. 1) were acquired from private collections, and at least one amber piece (MNHNSD FOS 17.01) was collected in La Toca mine belonging to La Toca Formation, dated as early middle Miocene (Iturralde-Vinent \& MacPhee, 1996). The other piece, having two fly specimens, originates from the Dominican Republic, from La Toca Formation but of unknown mine (SFM Be 12428). The specimens are preserved in two pieces of yellow-red amber with some impurities and one of them contains syninclusions. The pieces were cut, polished and embedded in Araldit 2020 to avoid future oxidation. The specimens were examined under a Nikon SMZ1000 stereomicroscope. Photographs were taken using a digital camera attached to a Nikon SMZ25 microscope. Drawings were made using a camera lucida attached to the Nikon SMZ1000 stereomicroscope.

The terminology follows Cumming and Wood (2017). Abbreviations of morphological features: $\mathrm{ad}=$ anterodorsal; $\mathrm{av}=$ anteroventral setae; $\mathrm{bm}=$ basal medial cell; $\mathrm{br}=$ basal radial cell; cerc $=$ cercus; $\mathrm{CuA}=$ anterior branch of cubital vein; cua $=$ anterior cubital cell; $\mathrm{CuA}+\mathrm{CuP}=$ anterior branch of cubital vein + posterior branch of cubital vein; $\mathrm{d}=\mathrm{dorsal}$ bristles; $\mathrm{dc}=$ dorsocentral bristles; $\mathrm{dm}=$ discal medial cell; epand = epandrium; $\mathrm{h}=$ humeral crossvein; hypd = hypandrium; $\mathrm{M}_{1}, \mathrm{M}_{4}=$ medial veins; $\mathrm{m}$-cu = medial-cubital crossvein; $\mathrm{pd}=$ posterodorsal; $\mathrm{pv}=$ posteroventral; $\mathrm{R}_{1}, \mathrm{R}_{2+3}=$ radial veins; $\mathrm{Rs}=$ radial sector; $\mathrm{Sc}=$ subcostal vein; $\mathrm{st}=$ sternite; sur $=$ surstylus; $\operatorname{tg}=$ tergite; $\mathrm{v}=$ ventral setae. 
One of the amber pieces (Fig. 1C) was donated by Jorge Caridad to the Museo Nacional de Historia Natural "Prof. Eugenio de Jesús Marcano", Santo Domingo, Dominican Republic (labelled MNHNSD FOS 17.01).

The electronic version of this article in Portable Document Format (PDF) will represent a published work according to the International Commission on Zoological Nomenclature (ICZN), and hence the new name contained in the electronic version is effectively published under that Code from the electronic edition alone. This published work and the nomenclatural act it contains have been registered in ZooBank, the online registration system for the ICZN. The ZooBank LSIDs (Life Science Identifiers) can be resolved and the associated information viewed through any standard web browser by appending the LSID to the prefix "http://zoobank.org/". The LSID for this publication is: urn: Isid:zoobank.org:pub: A143E982-0C6B-4B89-B157-ACAD969D3457.

\author{
RESULTS \\ Systematic Palaeontology \\ Order Diptera Linnaeus, 1758 \\ Family Hybotidae Meigen, 1820 \\ Syneproctus gen. nov.
}

(Figs. 1-2)

Type species: Syneproctus caridadi sp. nov., here designated. Monotypic genus.

Etymology. The name Syneproctus is a combination of Syneches and Stenoproctus Loew. The gender is masculine.

Diagnosis. Head hemispherical and holoptic in both sexes, eyes bare, frontally flattened and inflated, making the head wider than its height (from anterior view); postpedicel tapered with apical arista-like stylus; mouthparts stoutly sclerotized and slender, narrow and apically pointed, without pseudotracheae; palpus slender, much shorter than labrum with long apical setae; thorax highly arched; hind femur enlarged and spinose beneath; wings broad, with distinct pterostigma; Rs elongate, arising in proximal half of cell br; $\mathrm{m}$-cu crossvein horizontally orientated; vein $\mathrm{CuA}+\mathrm{CuP}$ not reaching the wing margin; cell cua shorter than cell bm; $\mathrm{CuA}$ slightly arched; cell dm enlarged, longer and broader than basal cells; male terminalia nearly symmetrical, lacking articulated surstyli, rotated $45^{\circ}$ to the right.

\title{
Syneproctus caridadi sp. nov.
}

(Figs. 1-2)

LSID urn:1sid:zoobank.org: pub: A143E982-0C6B-4B89-B157-ACAD969D3457.

Diagnosis. Pterostigma more than 3 times as long as wide, filling apical 0.3 of cell $\mathrm{r}_{1}$. Veins $\mathrm{R}_{4+5}$ and $\mathrm{M}_{1}$ not distinctly convergent apically. Hind femur swollen and bearing spine-like ventral setae mounted on short protuberances, the first seven on finger-like ventral tubercles, the other 11 on short elevations.

Diagnosis. Pterostigma 3 veces más largo que ancho, llenando apicalmente 0.3 de la celda $\mathrm{r}_{1}$. Venas $\mathrm{R}_{4+5}$ y $\mathrm{M}_{1}$ no claramente convergentes apicalmente. Fémur posterior hinchado y con setas ventrales emergiendo de protuberancias cortas, las primeras siete de tubérculos ventrales en forma de dedos, las otras once de elevaciones cortas. 
Holotype (male). DOMINICAN REPUBLIC. SMF Be 12428a and Allotype (female) $\mathrm{SMF}$ Be 12428b. Housed at Senckenberg Forschungsinstitut und Naturmuseum (Frankfurt, Germany). The holotype and allotype are present in the same amber piece, close together and in the same resin (amber) flow (layer) indicating spatial and temporal co-occurrence. Syninclusions: one Hymenoptera covered with micro bubbles, one male of Diptera: Psychodidae: Trichomyiinae, one male of Diptera: Chironomidae, and one Acari.

Paratype (female). DOMINICAN REPUBLIC. MNHNSD FOS 17.01. Housed at Museo Nacional de Historia Natural "Prof. Eugenio de Jesús Marcano". Without associated syninclusions.

\section{Description}

Holotype (male). Body length $4.25 \mathrm{~mm}$. Head: Eyes flattened dorsally and upper facets enlarged. Ocellar triangle elevated, bare and shiny; bearing 2 long ocellar bristles; postocular setae short and proclinate. Antenna placed at middle of head; scape and pedicel subcylindrical; pedicel larger than scape, with distal ring of setae; postpedicel pointed, bilaterally symmetrical, elongate, basally swollen, $0.15 \mathrm{~mm}$ length, $0.07 \mathrm{~mm}$ width; arista-like stylus terminal, $0.7 \mathrm{~mm}$ length, 2-articulated, basal article very short (Fig. 2C). Proboscis shorter than head. Palpus with 3 apical setae, second seta shorter and apical seta as long as palpus. Thorax: Scutum, scutellum and pleura shiny with some fine microsetae. Pronotum long with 1 strong marginal seta and 2 slender setae. Scutum rounded dorsally, greatly convex, with sparse slender setae; setae of prescutellar disc long and strong; acrostichal setulae and dorsocentral setulae uniserial; 1 supra-alar seta strong; scutum with pattern of color showing 4 black lines. One pair of apical scutellar spine-like bristles and 3 weak lateral bristles, two about 1/4 length of apical pair and one in middle of two small ones about $1 / 2$ length of apical pair. Legs clothed in slender and long setae, denser in tarsomeres. Fore femur slightly wider than mid femur. Fore tibia darker than mid and hind tibiae. Hind tibia geniculate at base. Outstanding bristles: Fore tibia with 2 av, 1 ad, $3 \mathrm{pv}$ and $1 \mathrm{pd}$ not reaching apex of corresponding tarsomere 1 . Fore tarsomere 1 with 1 long, posterior, robust preapical seta not extending beyond apex of fore tarsomere 2 . Mid tibia with 2 long robust av, 2 ad, 2 pv and $1 \mathrm{pd}$. Mid tarsomere 1 with 1 long posteroventral bristle near base, almost reaching base of tarsomere 2. Hind tibia with long simple setae and row of $18 \mathrm{v}$ shorter tuberculated spines. Hind tarsomere without spines, with dense short setae. Pulvilli all of same length. Hind femur thickened, 4.6 times as long as wide; with one seta at apical quarter, 1 ad near apex; row of 7 av long spines; row of $18 \mathrm{v}$ shorter tuberculated spines, tubercles more conspicuous on distal half. Wing (Fig. 2A): $3.8 \mathrm{~mm}$ length. Pterostigma more than 3 times as long as wide, light brown, filling apical 0.3 of cell $r_{1}$. Sc running very close to $\mathrm{R}_{1}$ and fading away. $\mathrm{R}_{4+5}$ and $\mathrm{M}_{1}$ not distinctly convergent apically. Cell $\mathrm{dm}$ large with short $\mathrm{M}_{4}$. Abdomen: broad, apparently flattened dorsoventrally. All tergites with long setae. Segment 8 rotated $45^{\circ}$. Terminalia: Epandrium with medially directed subapical pointed process (Fig. 2D); apex of epandrium (surstylus) tapered, medially directed with slender, pointed tooth-like apex. Hypandrium distinctly longer than wide, narrowed towards tip. Phallus difficult to observe but seems thin and acute (Fig. 2B).

Paratype (female). Similar to male. Body length $4.76 \mathrm{~mm}$. Legs: Hind trochanter with 2 robust posteroventral distal bristles. Hind femur as thickened as in male, 4.6 times as long as wide with $1 \mathrm{~d}$ seta at apical quarter, 1 ad near apex; row of 9 av long spines, basal seta shorter and not as strong as other 8 av; row of $18 \mathrm{v}$ shorter tuberculated spines (Fig. 2E). Terminalia: as in Fig. 2F.

Etymology. The species name caridadi is a dedication to the Dominican family Caridad, owners of the World Amber Museum in Santo Domingo. 
Remarks. To find male and female specimens of the same species is rather uncommon in the fossil record. In the amber piece SMF Be 12428, the male (Holotype), (Fig. 1, A, B and D), and female (Allotype; Fig. 1, A, E) are preserved together. They appear head to head, not in copula position but originally in the same resin layer. Present in this amber piece there are other syninclusions; however, these were trapped at different times, thus in different resin layers. We consider the exemplars conspecific because they share all the relevant morphological characters and only the few differences they show could be considered of sexual dimorphism. We choose to describe the paratype female and not the allotype because of the favorable position of the specimen in the piece of amber that allow much better visibility and presentation of the characters. However, all the relevant characters have been observed in both specimens.
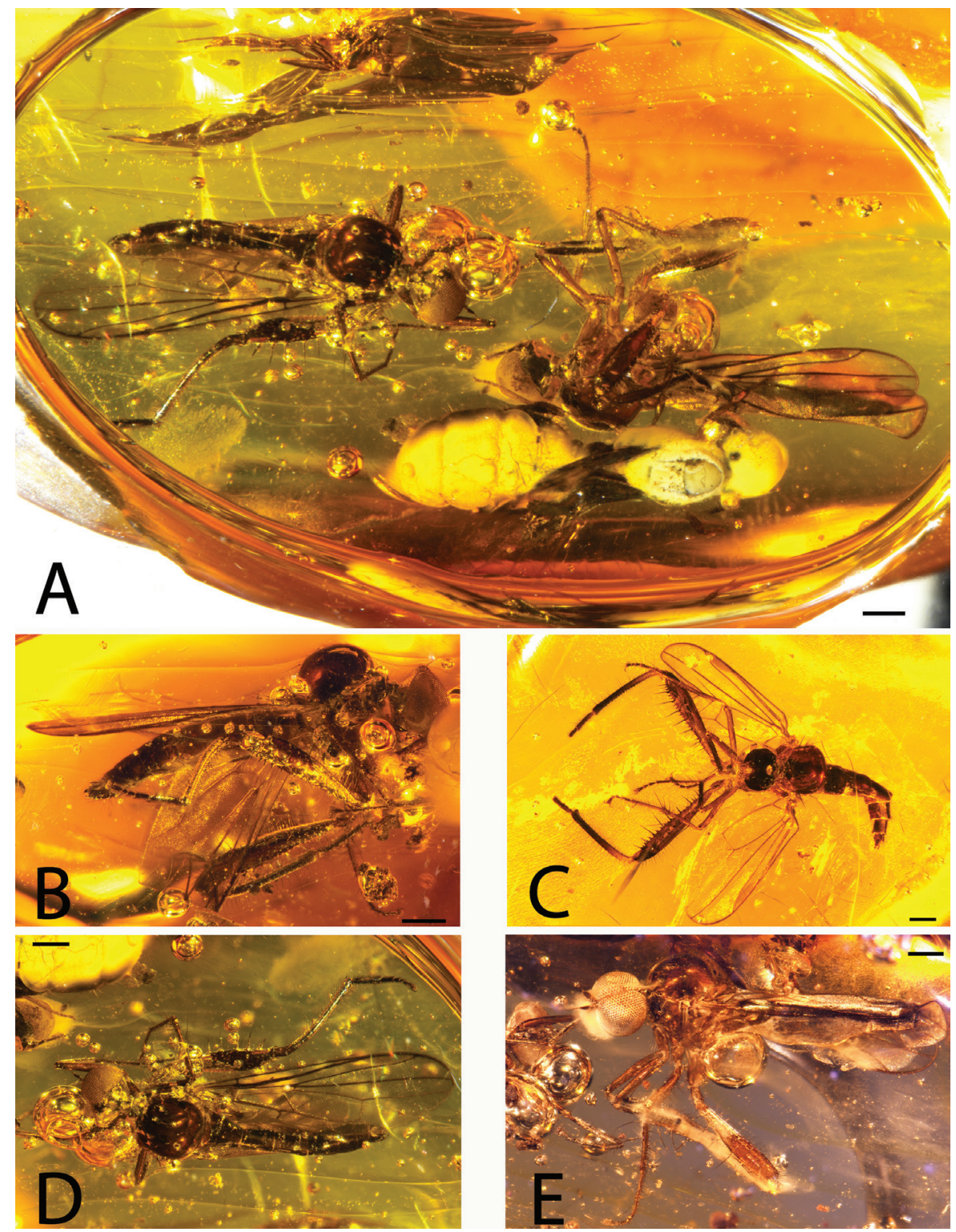

Figure 1. Photographs of Syneproctus caridadi gen. et sp. nov. (Empidoidea, Hybotidae). A, SMF Be 12428, general view of the amber piece with the holotype ( $\delta^{\star}$; right) and the allotype ( + ; left) very close to each other. B and $\mathrm{D}$, holotype $\left(\delta^{\star}\right)$ SMF Be 12428a, habitus in different views. C, paratype (q) MNHNSD FOS 17.01, habitus. E, allotype (q) SMF Be $12428 \mathrm{~b}$ habitus. Scale bars $=0.5 \mathrm{~mm}$. 

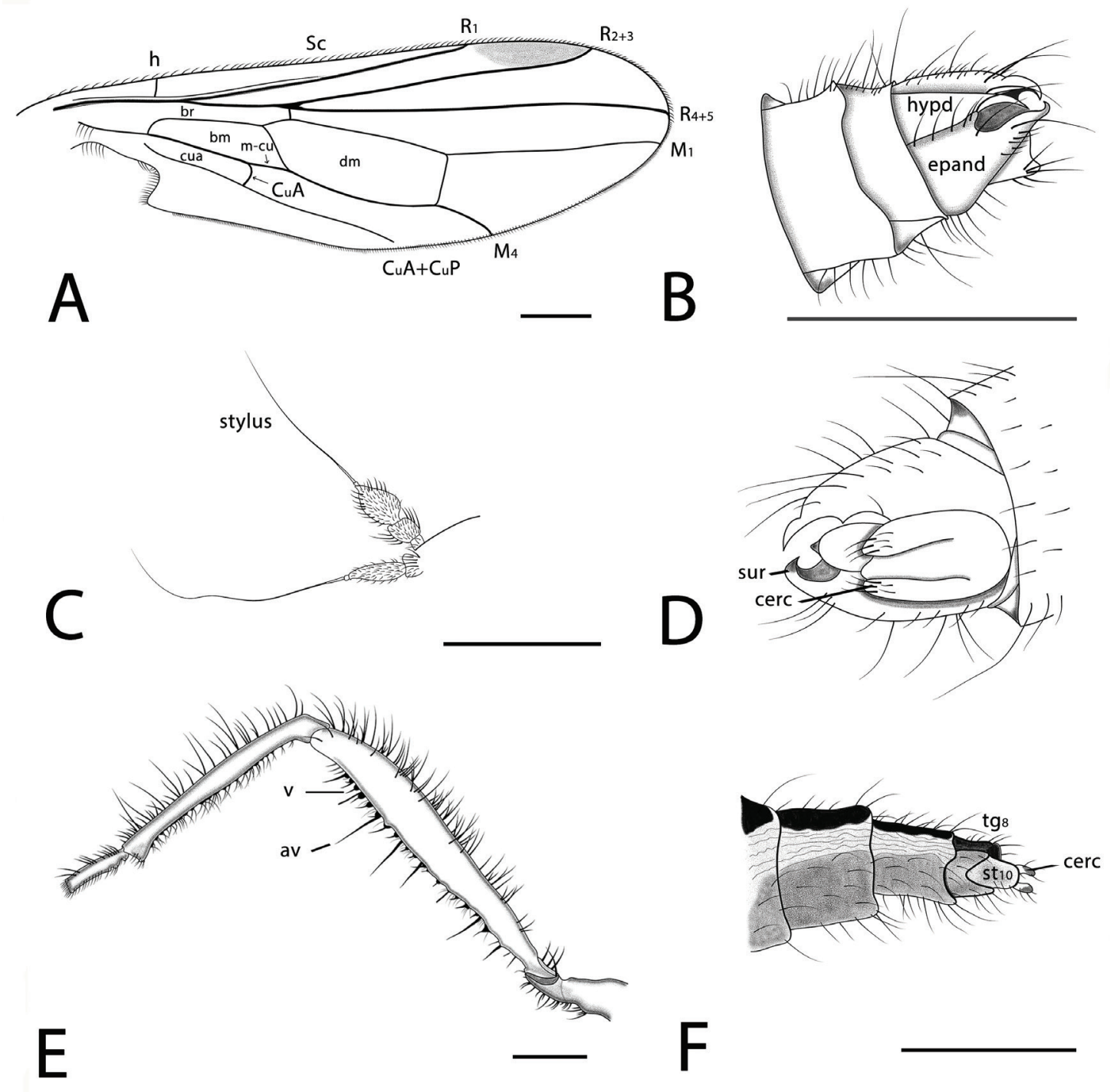

Figure 2. Camera lucida drawings of the major anatomical features of Syneproctus caridadi gen. et sp. nov. (Empidoidea, Hybotidae). A-D, holotype ( $\left.\widehat{O}^{\top}\right)$ SMF Be 12428a. A, wing. B, terminalia in dorsal view. C, antennae. D, terminalia in ventral view. E-F, paratype () MNHNSD FOS 17.01. E, detail of the hind leg. F, terminalia in ventral view. Scale bars $=0.5 \mathrm{~mm}$. 


\section{DISCUSSION}

In the key to genera of Neotropical Hybotinae by Ale-Rocha and Carvalho (2003), the new genus runs to Syneches. Syneproctus gen. nov. is distinguished from Syneches by the more tapered postpedicel, horizontally orientated crossvein m-cu and cell cua much shorter than cell bm. In Syneches, the postpedicel is apically oval, m-cu is obliquely positioned and cell cua is long, extending beyond cell bm. The wing venation of the new genus is more like that of the Afrotropical genus Stenoproctus Loew, 1858. The nearly horizontally orientated crossvein $\mathrm{m}$-cu creates a straight line connection between cells bm and $\mathrm{dm}$, and the shortened cell cua is somewhat similar to Stenoproctus (see Sinclair \& Cumming, 2017, fig. 20). But unlike Stenoproctus, with its more membranous proboscis and presence of pseudotracheae, the proboscis of Syneproctus gen. nov. is stout and heavily sclerotized and Syneches-like. Species of the new genus were probably predaceous on the basis of the piercing like proboscis shared with other genera of Hybotinae. The new genus is also very similar to Chillcottomyia Saigusa, 1986, known from the Afrotropical and Oriental regions (Sinclair \& Cumming, 2017), which is characterized by pubescent eyes (short ommatrichia), slender hind femora and mouthparts similar to Stenoproctus. Syneproctus gen. nov. differs by having bare eyes, enlarged hind femora and Syneches-like proboscis.

\section{ACKNOWLEDGMENTS}

We thank Mr. Jorge Caridad (World Amber Museum, Santo Domingo) and his family for the loan of the piece MNHNSD FOS 17.01 for study, and for its donation to the Museo Nacional de Historia Natural "Prof. Eugenio de Jesús Marcano", Santo Domingo. Thanks also to Claudia Franz (SMF) for the management of the amber collection and Robin Kunz for photography and digitization of the drawings (SMF). The comments of Carlos Suriel (Editor) and two anonymous reviewers also improved the manuscript.

\section{Additional information and declarations}

Funding. Financial support was provided by the VolkswagenStiftung project 90946 and the Spanish Ministry of Economy and Competitiveness (project "CRE", Spanish AEI/FEDER, UE CGL2017-84419).

\section{LITERATURE CITED}

Ale-Rocha, R., \& C. J. B. De Carvalho. 2003. Neohybos gen. nov. (Diptera, Empidoidea, Hybotinae) from the Neotropical Region. Zootaxa, 387: 1-16.

Ale-Rocha, R., \& J. A. Rafael. 2004. Hybotinae (Diptera, Empidoidea, Hybotidae) from the Dominican Republic: new records and descriptions of new species. Revista Brasileira de Entomologia, 48 (4): 495-508.

Cumming, J. M., \& D. M. Wood. 2017. 3. Adult morphology and terminology, pp. 89-133. In A. H. Kirk-Spriggs, and B. J. Sinclair (Eds.), Manual of Afrotropical Diptera. Volume 1, Introductory chapters and keys to Diptera families. Suricata 4. South African National Biodiversity Institute, Pretoria.

Iturralde-Vinent, M. A. 2001. Geology of the amber-bearing deposits of the Greater Antilles. Caribbean Journal of Science, 37: 141-167. 
Iturralde-Vinent, M. A., \& R. D. E. MacPhee. 1996. Age and paleogeographical origin of Dominican amber. Science, 273 (5283): 1850-1852.

Iturralde-Vinent, M. A., \& R. D. E. MacPhee. 2019. Remarks on the age of Dominican amber. Palaeoentomology, 2 (3): 236-240.

Menezes, I. S., \& R. Ale-Rocha. 2016. Revision of the Amazonian species of Syneches Walker (Diptera, Hybotidae, Hybotinae). Zootaxa, 4103 (5): 401-442.

Penney, D. (Ed.). 2010. Biodiversity of fossils in amber from the major world deposits. Manchester, United Kingdom: Siri Scientific Press, 304 pp.

Sinclair, B. J., \& J. M. Cumming. 2006. The morphology, higher-level phylogeny and classification of the Empidoidea (Diptera). Zootaxa, 1180: 1-172.

Sinclair, B. J., \& J. M. Cumming. 2017. 52. Hybotidae (hybotid dance flies), pp. 1237-1249. In A.H. Kirk-Spriggs, and B. J. Sinclair (Eds.), Manual of Afrotropical Diptera. Volume 2, Nematocerous Diptera and lower Brachycera. Suricata 5. South African National Biodiversity Institute, Pretoria.

Solórzano-Kraemer, M. M., X. Delclòs, M. Clapham, A. Arillo, D. Peris, P. Jäger, F. Stebner, \& E. Peñalver. 2018. Arthropods in modern resins reveal if amber accurately recorded forest arthropod communities. Proceedings of the National Academy of Sciences, 115 (26): 6739-6744. https://doi.org/10.1073/pnas.1802138115.

Solórzano-Kraemer, M. M., B. J. Sinclair, \& J. M. Cumming. 2005. Five new species of Tachydromiinae (Diptera: Empididae sl.) from New World Tertiary ambers. Zootaxa, 1010: 37-52.

Wilder, D. D. 1974. A revision of the genus Syneches Walker (Diptera: Empididae) for North America and the Antilles. Contributions of the American Entomological Institute, 10: 1-30.

[Recibido: 23 de abril, 2019. Aceptado para publicación: 05 de agosto, 2019] 